\title{
COMPARING HABITAT PREFERENCES OF A SET OF WATERBIRD SPECIES WINTERING IN THE COASTAL WETLANDS OF NORTH AFRICA: IMPLICATION FOR MANAGEMENT
}

\author{
ALI ELAFRI ${ }^{1,2^{*}}$, MOUHAMED BELHAMRA $^{3}$, MOUSSA HOUHAMDI $^{4}$ \\ ${ }^{1}$ Department of Biology and Animals Physiology, Faculty of Natural Science, Ferhat Abbas Setif-1 University, El- \\ Bez, Sétif, 19000, Algérie \\ ${ }^{2}$ Département des Sciences de la Nature et de la Vie, Centre Universitaire Abdelhafid Boussouf, Mila 43000, Algérie; \\ e-mail: a.elafri@centre-univ-mila.dz \\ ${ }^{3}$ Laboratoire de Diversité des Ecosystèmes et Dynamiques des Systèmes de Production Agricoles en Zones \\ Arides,Département d’agronomie, Université Mohamed Khider, Biskra 07000, Algérie \\ ${ }^{4}$ Laboratoire Biologie, Eau \& Environnement (LBEE), Faculté SNV-STU, Université 8 Mai 1945 Guelma, Algérie
}

*Author for correspondence

Abstract

Elafri A., Belhamra M., Houhamdi M.: Comparing habitat preferences of a set of waterbird species wintering in coastal wetlands of North Africa: implication for management. Ekológia (Bratislava), Vol. 36, No. 2, p. 158-171, 2017.

Every year, the Coastal wetlands of North Africa support an important wintering waterbird population of many Palearctic and sub-Saharan species of various contrasting habitat requirements. In this study, we describe the habitat use by 24 water-obligate species wintering in a coastal wetland of the Northeastern Algeria (the wetland of Lake Tonga), highlighting thereby the ecological mechanisms that support their coexistence and their resources partitioning. The analysis of resource exploitation (Relative frequency, Feinsinger niche breadth, Pianka niche overlap and Ivlev's electivity indexes) showed that waterbird species inhabiting the lake wetland have several similarities in using the different habitat categories, which lead us to cluster them into 5 guilds (G1: one rails, two grebes and eight ducks; G2: five wading species and one gull; G3: three herons; G4: cormorants, mallards, and on gull; finally, G5: only one species Cattle egret (Bubulcus ibis).Almost all the species were specialists in resource utilization patterns (narrow niche breadths, both under 0.3 ) and therefore, vulnerable to fluctuations in resources, particularly the feeding habitats. Mean niche overlaps for all the pairs of species ranged from 0.05 to 0.68 . The overall pattern in the community was higher niche overlaps between the species of a particular guild than those between other species. According to Ivlev's electivity index, we found that only three microhabitats from seven were the most important for the discussed species, open water body was the most attractive, followed by meadows, muddy areas and floating-leafed vegetation. Similarities on habitat requirements derived from our region can provide important and optimal wetland management at multi-species assemblage level for this wetland and similar area around the African coast.

Key words: cluster analyses, coastal wetlands, electivity index, niche breadth, niche overlap, waterbirds. 


\section{Introduction}

Habitat loss and degradation is a main driver of worldwide biodiversity loss (Tellería, 2016). In this context, it is important to establish management guidelines that conserve habitats and species based on a sound knowledge of wildlife-habitat relationships (Tellería, 2016). Wetlands are among the most productive habitats in the world, which provide numerous beneficial services for people, for fish and several avian species depend on them (Sulphey, Safeer, 2014).Nevertheless, they have suffered more loss and degradation than any other habitats(Shine, Klemm, 1999; Sulphey, Safeer, 2014). Water-related bird species are among the most sensitive component of theses ecosystems. Therefore, understanding their habitat preferences and ecological mechanisms that support their coexistence is a fundamental issue for effective nature conservation. One of the principal factors that influence the structure of waterbird communities is the partitioning of resources (either food or space)and it may be driven by the large number of water-related variables affecting species interactions (PérezCrespo et al., 2013). Most studies searching for patterns of resource utilization (food and space) evaluated niche breadth and niche overlap (Krebs, 1999; Pérez-Crespo et al., 2013). Niche breadth is an important parameter forthe evaluation of the level of dietary specialization; species with niches of reduced breadth are relatively specialized, whereas more ample niches are typical of generalist species (Colwell, Futuyma, 1971; Krebs, 1999; Pérez-Crespo et al., 2013). The analysis of niche overlap also provides an important approach to answer the question: How do the different species partition the resources in the community? If species overlap in niches to a great extent, they may influence each other's population growth through interspecific competition (Colwell, Futuyma 1971; Krebs, 1999; Pérez-Crespo et al., 2013).

The North African coast supports important wintering waterbird populations and is located in the migratory flyways (Palearctic-African migration) of many Palearctic and subSaharan species (Liordos, 2010; Elafri et al., 2016). The coastal wetlands of North Africa are therefore critical foraging areas for many waterbirds during winter and migration periods, since they must build up sufficient fat reserves, which are crucial for their survivaland breeding on nesting grounds(Samraoui, B., Samraoui, F., 2008; Liordos, 2010). In coastal wetlands of north Africa, a wide literature has been recognized on the link between habitats and waterbirds' life history, but the focus often was on single species, especially the endangered ones such as Marbled duck Marmaronetta angustirostris, Ferruginous duck Aythya nyroca and white-headed duck Oxyura leucocephala (see Green, Hamzaoui, 2000; Meziane et al., 2014; Fouzari et al., 2015). Also, all the studies considered only the breeding season and there have been no studies taking a habitat perspective in large, multi-species assemblages through the year,as referred in similar wetlands around the south European coast(see Green, 1998; Paracuellos, 2006; Liordos, 2010; Rizzo, Battisti, 2009). Lack of these data could generate implications in conservation and management strategies focused on these wetland-associated species (Elmberg et al., 2006). Therefore, we describe in this study the habitat use of a subset of water-obligate species wintering in a coastal wet area of Northeastern Algeria (the wetland of Lake Tonga), highlighting thereby the ecological mechanisms that support their coexistence and their resources partitioning. Simultaneous comparisons of resource use by multiple 
species assemblage in the same area can provide important insights regarding alternatives for wetland development, restoration and management.

\section{Material and methods}

\section{Study area}

Lake Tonga $\left(36^{\circ} 51^{\prime} \mathrm{N}, 8^{\circ} 30^{\prime} \mathrm{E}\right)$ is a shallow freshwater marsh of 2,700 ha situated in the extreme north-east of Algeria near the Algerian-Tunisian border at $3 \mathrm{~km}$ of the Mediterranean Sea and flows into it through an artificial channel (Fig. 1). Almost $80 \%$ of its area is covered by helophytes and hydrophytes dominated by Scirpus lacustris, Typha angustifolia, Nymphaea alba, Salix atrocinerea and Phragmites australis (Elafri et al., 2016).Therefore, it involved a wide range of habitat units such as grassland, marsh swamp, lotus swamp and open water body. Among birds, this area hosts more than 25,000 wintering birds (mainly ducks, coots and colonial birds)(Elafri et al. 2016).It is designated as a Ramsar site since 1983 and is part of the El Kala National Park (PNEK), Wilaya of El-Taref (Lazli et al., 2011). The PNEK is a Man and Biosphere Reserve, part of an extensive wetland complex spread across northeast Algeria and housing a wide range of Important Bird Areas (IBA) and Ramsar sites (Samraoui, B., Samraoui, F., 2008). The climate in the region is typically Mediterranean, characterized by warm to hot, dry summers and mild to cool, wet winters (Boumezbeur, 1993).

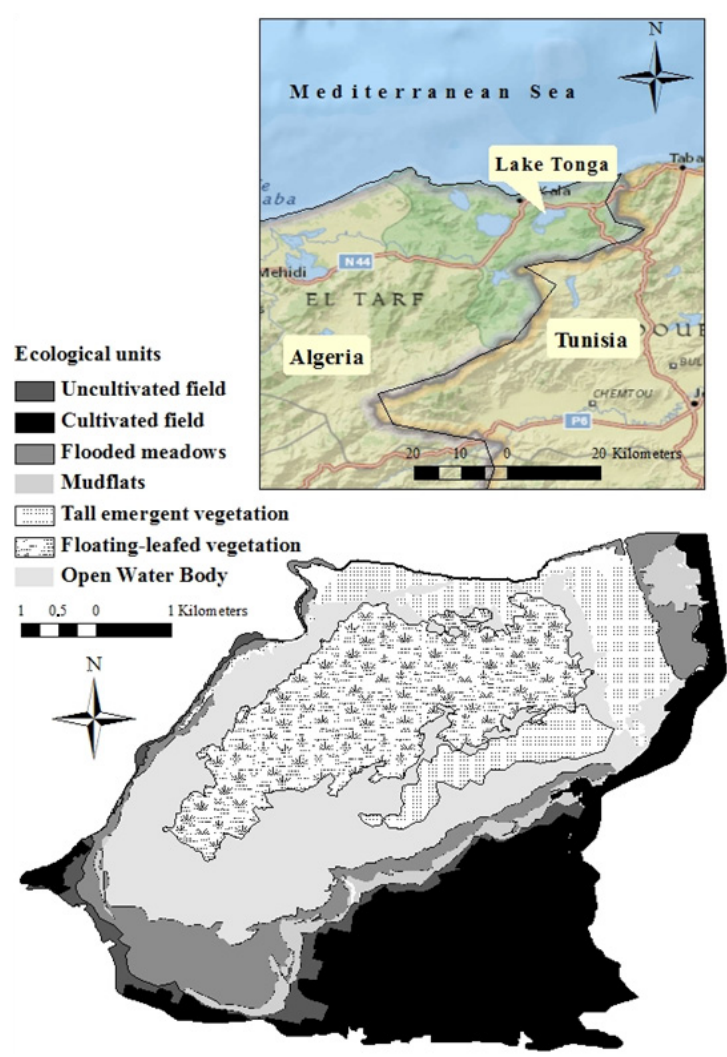

Fig. 1. Map of Lake Tonga including the seven habitat categories.

\section{Birds and habitats survey}

We made a field map based on photo-interpretation of an aerial photograph and satellite images (Google earth explorer) taken in the wintering season (2014-2015). We have also delimited the natural contours of habitats by investigating the area. The vegetation data were synthesized from the available references and observations. The entire study site was divided into seven major blocks based on landscape elements observed in winter (Table 1). The data on birds presented in this work was directly gathered from our observation through the vantage points that were chosen because of their relative accessibility and unhindered view, using a 20-40x60 telescope (Konus Spotting Scope) from September 2014 to February 2015.

\section{Data analyses}

We refer to the entire set of values around winter, not subdividing data monthly. We calculated the abundance (i.e., the number of individuals recorded; $n$ ) and frequency (the ratio number of individuals/total; fr) of each bird in each of the selected land use/cover habitat types. Firstly, a hierarchical cluster analysis grouped birds according to the frequency of each species in each of the selected land use/cover habitat types into the most similar clusters (Krebs, 1999). This cluster analysis was tested numerous times in order 
$\mathrm{T}$ a b l e 1. Landscapes elements of the seven blocks.

\begin{tabular}{|l|c|c|c|l|}
\hline Habitat & Abbreviation & Surface (ha) & $\begin{array}{c}\text { Percentage of } \\
\text { wetland surface (\%) }\end{array}$ & Description \\
\hline $\begin{array}{l}\text { Cultivated field } \\
\text { (Agricultural field) }\end{array}$ & CULF & 754.8 & 25.32 & $\begin{array}{l}\text { Land planted with an agricul- } \\
\text { tural crop (did not distinguish } \\
\text { between the types of crops } \\
\text { planted). }\end{array}$ \\
\hline $\begin{array}{l}\text { Uncultivated field } \\
\text { (Grassy field) }\end{array}$ & UNCF & 119 & 20.96 & $\begin{array}{l}\text { Open land vegetated with grass- } \\
\text { es and forbs, never flooded. }\end{array}$ \\
\hline Flooded meadows & FLM & 368.76 & 11.34 & $\begin{array}{l}\text { Open land vegetated with grass- } \\
\text { es and forbs, periodically flood- } \\
\text { ed in November-June period. }\end{array}$ \\
\hline Mudflats & MUD & 112.93 & 3.52 & $\begin{array}{l}\text { Any exposed wet ground be- } \\
\text { tween the water and dry land, } \\
\text { never vegetated. }\end{array}$ \\
\hline $\begin{array}{l}\text { Tall emergent } \\
\text { vegetation }\end{array}$ & TEV & 363.05 & 11.52 & $\begin{array}{l}\text { Corresponding to patches at } \\
\text { macrophytes }>50 \text { cm (Common } \\
\text { club-rush and reed bed). }\end{array}$ \\
\hline $\begin{array}{l}\text { Floating-leafed } \\
\text { vegetation }\end{array}$ & FLV & 671 & 3.71 & $\begin{array}{l}\text { Corresponding to the Nym- } \\
\text { phaeid area. }\end{array}$ \\
\hline Open Water Body & OWB & 810.4 & 23.58 & $\begin{array}{l}\text { Larger and open area dominated } \\
\text { by submerged vegetation. }\end{array}$ \\
\hline
\end{tabular}

to achieve the 'best'clustering (paired group UPGMA method to aggregate data and the Bray-Curtis method to calculate distances) (Krebs, 1999).Then, for each species, we obtained the following indices:

- Feinsinger niche breadth index (Feinsinger et al., 1981), as: PS $=\mathbf{1 - 0 . 5} \boldsymbol{\Sigma}\left|\mathbf{p}_{\mathrm{i}}-\mathbf{q}_{\mathrm{i}}\right|$, to evaluate the ability to use resources in comparison to their availability (an index of habitat preference). In the index, $\mathbf{p}_{\mathrm{i}}$ is the proportion of utilized resource (i.e., the frequency of records in every one of the seven habitat types) and $\mathbf{q}_{i}$ is the proportion of available resource (i.e., the frequency of each land habitat type in the total study area). The index varies from $\mathbf{0}$ (extreme specialist for that specific resource) to $\mathbf{1}$ (extreme generalist).

- $\quad$ Niche overlap was calculated with the index of Pianka (1973):

$\mathbf{O} \mathbf{j k}=\left(\Sigma \mathbf{p}_{\mathrm{ij}} \mathbf{p}_{\mathrm{ik}}\right)\left(\Sigma \mathbf{p}_{\mathrm{ij}}{ }^{2} \mathbf{p}_{\mathrm{ik}}{ }^{2}\right)^{-1 / 2}$, where $\mathbf{p}_{\mathrm{ij}}$ and $\mathbf{p}_{\mathrm{ik}}$ are proportional values of utilization of resource $\mathbf{i}$ by species $\mathbf{j}$ and $\mathbf{k}$, respectively. Pianka's index is symmetrical and assumes values ranging from $\mathbf{0}$ (no resources used in common between two species) to $\mathbf{1}$ (complete overlap in resource use).

- For each month, for each habitat category, Ivlev's electivity index (s) was calculated as $\mathbf{S}=(\mathbf{a}-\mathbf{b}) /(\mathbf{a}+\mathbf{b})$, where $\mathbf{a}$ was the percentage of population using a given habitat and $\mathbf{b}$ is the habitat area as a percentage of the total available habitat area (Jacobs, 1974). Electivity values indicate relative habitat use; values range between $\mathbf{- 1 . 0}$ (habitat never used) and $+\mathbf{1 . 0}$ (habitat exclusively used), with $\mathbf{0 . 0}$ representing habitat used in proportion with its availability (Wood, Stillman, 2014). Hence, the positive and negative electivity values indicated habitat preference and avoidance, respectively.

\section{Results}

\section{Guilds establishment and habitat preferences}

According to the similarity levels in patterns of using seven habitat categories by 24 waterbird species during the non-breeding period (September 2014 to February 2015), cluster analysis 
(average Euclidean distance of 0.6) defined five guilds (group of species mostly frequent the same habitat categories) (Fig. 2). The first guild (G1)was the most diversified and comprised 11 species: one rails (Eurasian coot Fulica atra); two grebes (Little grebe Tachybaptus ruficollis; Great crested grebe Podiceps cristatus) and eight ducks (White-headed duck; Ferruginous duck; Eurasian teal Anas crecca; Northern shoveller A. clypeata; Gadwall A. strepera; Common pochard Aythya ferina; Tufted duck A. fuligula; Eurasian wigeon Anas penelope). This group of species mostly frequent OWB $(97.37 \%$ of the observed individuals) if compared with other habitat types (Table 2). Guild 2 (G2) comprised five wading species (Black-winged Stilt Himantopus himantopus; Glossy Ibis Plegadis falcinellus; Purple Swamphen Porphyrio porphyrio; Common Moorhen Gallinula chloropus; Northern Lapwing Vanellus vanellus), and one gull (Black-headed Gull Chroicocephalus ridibundus). Species in this guild occurred in several habitat types but with some preferences to FLM (58.93\%), MUD (17.53) and OWB (12.32). Then, three herons: Little egret, Great egret and Grey heron formed (G3)occurred in six habitat categories, with higher proportion (58.16\%) in OWB and with lower proportion in TEV, FLV, MUD, FLM and UNCF. Great Cormorant Phalacrocorax carbo, Mallard Anas platyrhynchos, and Slender-billed Gull Chroicocephalus genei, which comprised G4, were chiefly observed in FLV (69.34\%). Finally, G5 included only one species Cattle egret Bubulcus ibis that has a unique pattern in using the different habitat categories of this wetland ecosystem, often occurred in UNCF and CULF.

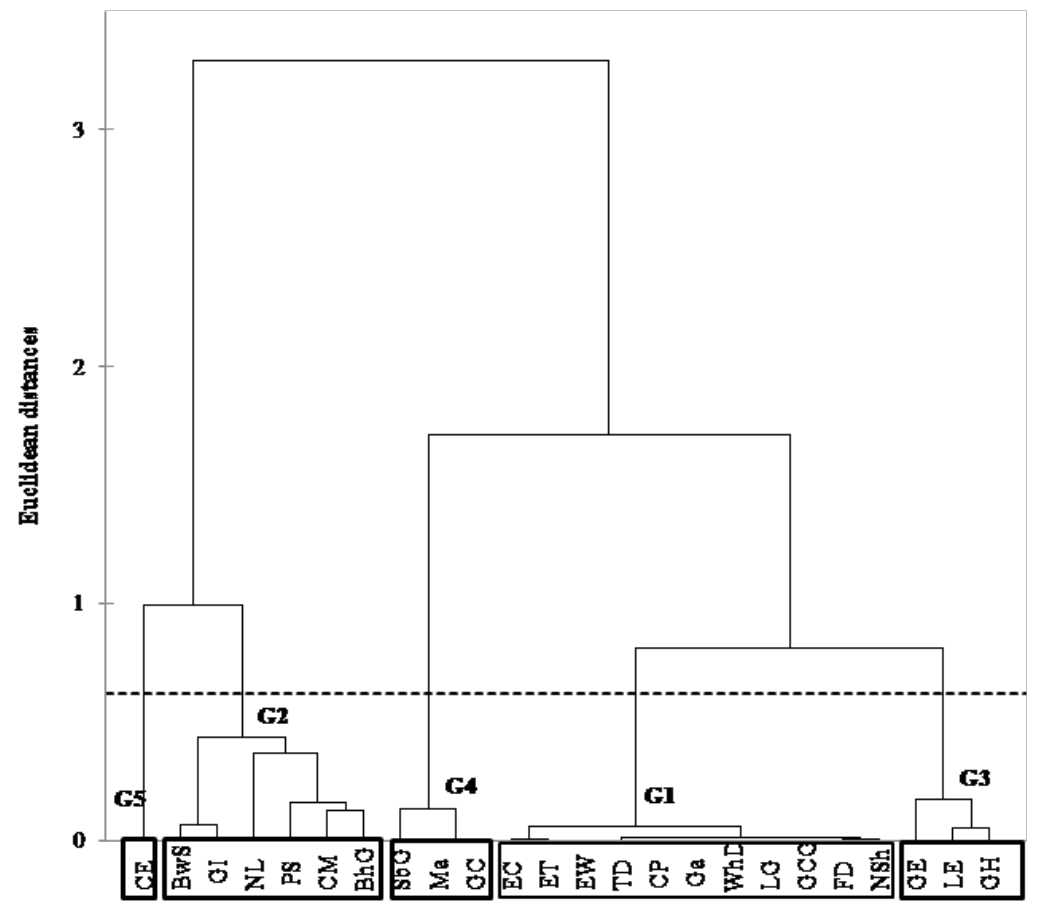

Fig. 2. Cluster analysis of waterbird species by habitat use similarities. The average Euclidean distances between all species pairs are marked with a dashed line (0.6). 
T a b le 2. Abundance (n) and relative frequency (fr) of five guild species in the seven selected habitat types in Tonga wetland (Northeast Algeria) in the 2014/2015 non-breeding period.

\begin{tabular}{|c|c|c|c|c|c|c|}
\hline \multicolumn{7}{|c|}{ Guild } \\
\hline \multicolumn{2}{|c|}{ Habitat } & G1 & G2 & G3 & G4 & G5 \\
\hline \multirow{2}{*}{ OWB } & $n$ & 27285 & 328 & 827 & 775 & 13 \\
\hline & $f r$ & 97.37 & 12.32 & 58.16 & 29.89 & 3.02 \\
\hline \multirow{2}{*}{ FLV } & $n$ & 0 & 140 & 218 & 1798 & 0 \\
\hline & $f r$ & 0 & 6.15 & 15.33 & 69.34 & 0 \\
\hline \multirow{2}{*}{ TEV } & $n$ & 196 & 66 & 242 & 4 & 2 \\
\hline & $f r$ & 0.70 & 2.90 & 17.02 & 0.15 & 0.46 \\
\hline \multirow{2}{*}{ MUD } & $n$ & 260 & 359 & 23 & 0 & 0 \\
\hline & $f r$ & 0.92 & 17.53 & 1.62 & 0 & 0 \\
\hline \multirow{2}{*}{ FLM } & $n$ & 282 & 1342 & 60 & 16 & 2 \\
\hline & $f r$ & 1.00 & 58.93 & 4.22 & 0.62 & 0.46 \\
\hline \multirow{2}{*}{ UNCF } & $n$ & 0 & 49 & 52 & 0 & 251 \\
\hline & $f r$ & 0 & 2.15 & 3.66 & 0 & 58.24 \\
\hline \multirow{2}{*}{ CULF } & $n$ & 0 & 0 & 0 & 0 & 163 \\
\hline & $f r$ & 0 & 0 & 0 & 0 & 37.82 \\
\hline
\end{tabular}

\section{Niche measurements}

In general, the niche breadth ranged from null (0) to moderate $(0.23)$ among the five guilds (Table 3). Species of G1and G4, among them the endangered White-headed Duck and Ferruginous Duck, showed a much lower niche breadth values; these were therefore extreme specialist as compared to the community, and occurred mostly in one habitat category. Guilds G2, G3 and G5 showed a moderate niche breadth index (0.18 to 0.23 ). Species of these three guilds were moderately generalists; they owned certain flexibility in habitat use.

Niche overlaps were calculated to answer the question: How do the different species partition the resources (space) in the community? Mean niche overlaps for all pairs of species ranged from 0.05 to 0.68 (Table 4 ). The overall pattern in the community was higher niche overlaps between the species of a particular guild than those between other species (Table 4).

Species belonging to G1 (mostly frequent OWB)overlapped more than the remaining species in other guilds. Niche overlap values for all pairs of species belonging to this guild were never under 0.64 , that is, there was large overlap in resource (space) use within bird community. We also note that guilds occurring in several habitat types as G2, G3, G4 and G5 showed the minimum niche overlap values (very close to 0 ), that is,resources (space) are low if not used as common between all pairs of the species.

Among species, Cattle egret showed a very low mean niche overlap of 0.05 (Table 3); this bird does not share any resources within community. Flowed by Mallard, Great cormorant, and Black Winged Stilt, both of which have niche overlap values under 0.20 . Therefore, the population growth of these birds may be less influenced through interspecific competition. 
T a b l e 3. Feinsingerniche breadth index for the waterbird species in Tonga wetland among the 2014/2015 nonbreeding period.

\begin{tabular}{|c|c|c|c|}
\hline Guild & Species & Code & Index $(n=7)$ \\
\hline & Eurasian Coot & $\mathrm{EC}$ & 0.01 \\
\hline & Eurasian Teal & ET & 0.01 \\
\hline & Eurasian Wigeon & EW & 0.00 \\
\hline & Tufted Duck & TD & 0.00 \\
\hline & Common Pochard & $\mathrm{CP}$ & 0.00 \\
\hline & Gadwall & $\mathrm{Ga}$ & 0.00 \\
\hline & White-headed Duck & WhD & 0.00 \\
\hline & Little Grebe & LG & 0.00 \\
\hline & Great Crested Grebe & GCG & 0.00 \\
\hline & Ferruginous Duck & $\mathrm{FD}$ & 0.01 \\
\hline & Northern Shoveller & NSh & 0.00 \\
\hline \multirow[t]{7}{*}{ G1 } & Mean & & 0.00 \\
\hline & Black-winged Stilt & BwS & 0.20 \\
\hline & Glossy Ibis & GI & 0.20 \\
\hline & Northern Lapwing & $\mathrm{NL}$ & 0.12 \\
\hline & Purple Swamphen & PS & 0.10 \\
\hline & Common Moorhen & $\mathrm{CM}$ & 0.27 \\
\hline & Black-headed Gull & BhG & 0.16 \\
\hline \multirow[t]{4}{*}{ G2 } & Mean & & 0.18 \\
\hline & Little Egret & LE & 0.24 \\
\hline & Great Egret & GE & 0.22 \\
\hline & Grey Heron & GH & 0.26 \\
\hline \multirow[t]{4}{*}{ G3 } & Mean & & 0.23 \\
\hline & Mallard & $\mathrm{Ma}$ & 0.04 \\
\hline & Slender-billed Gull & SbG & 0.17 \\
\hline & Great Cormorant & GC & 0.04 \\
\hline \multirow[t]{2}{*}{ G4 } & Mean & & 0.08 \\
\hline & Cattle Egret & $\mathrm{CE}$ & 0.18 \\
\hline G5 & Mean & & 0.18 \\
\hline
\end{tabular}

In contrast, the endangered species as Ferruginous duck and White-headed duck overlap in niches to a great extent (higher mean niche overlap between all pair of species, 0.65) and would have been more affected through intense interspecific competition (Table 4).

\section{Discussion}

The wintering period is a critical period in the yearly cycle of waterbirds, since sufficient energy supplements are critical to their migration, reproduction and survival (Both et al., 2010). At this time, large flocks of migratory birds such as ducks, shorebirds and coots are housing the study area (Elafri et al., 2016). High congregations coupled with food, extremely 
คी

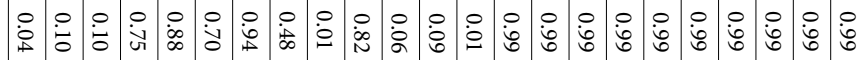

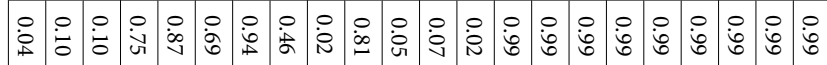

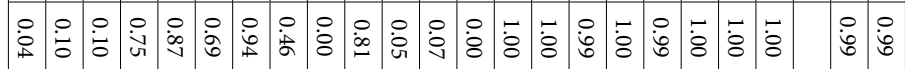

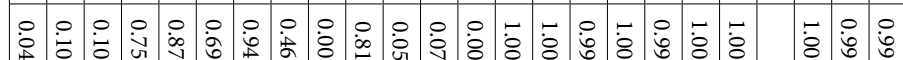

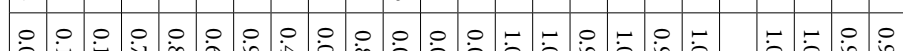

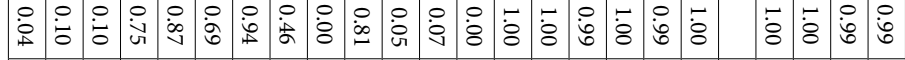

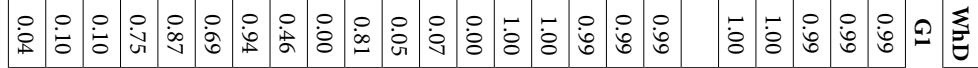

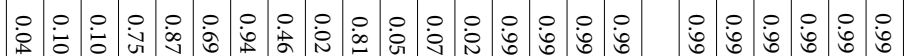

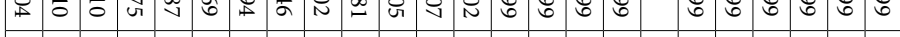

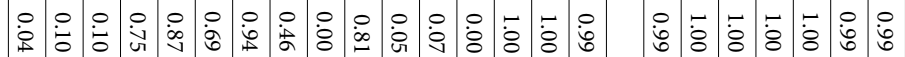

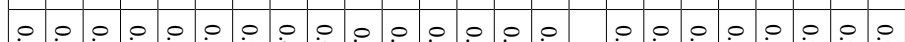

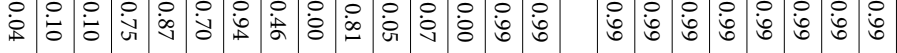

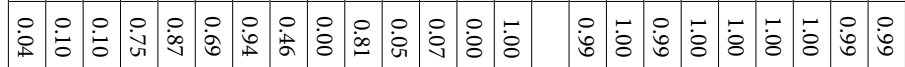

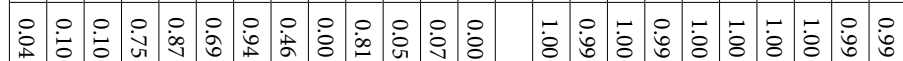

○

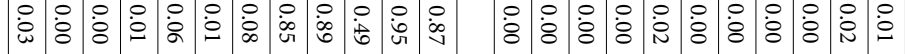

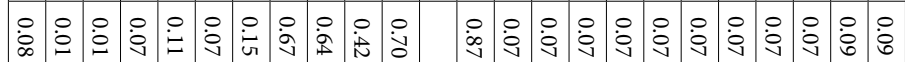

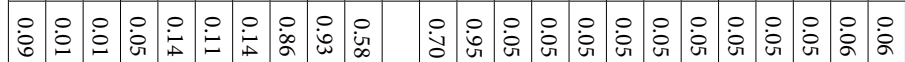

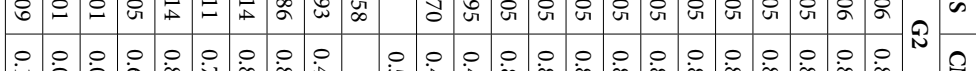

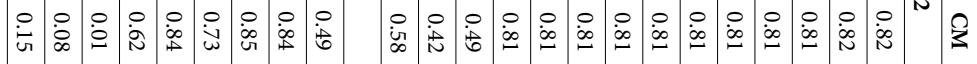

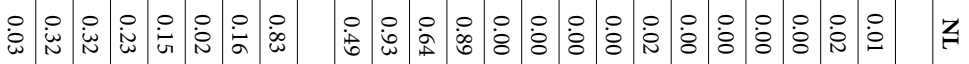

0000000 0 0 0 0 0 0 0 0 0 0 0 0 0 0 0 0

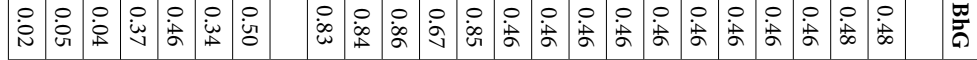

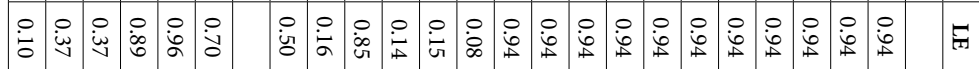

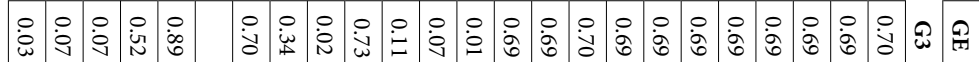

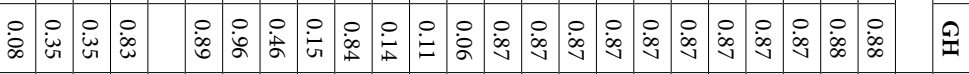

离岀空

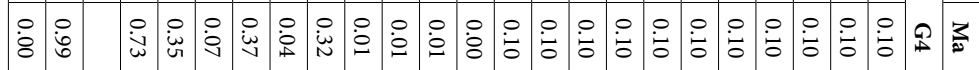

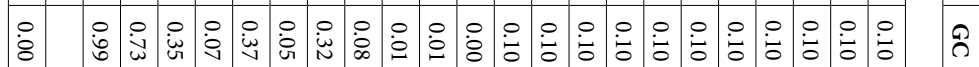

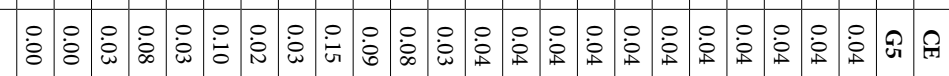

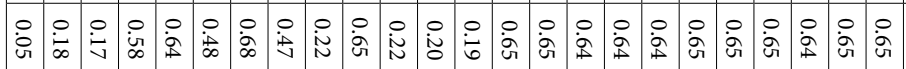


limited space and other resources, leading thereby to maximize potential interspecific competition among bird community. Collecting data on habitat utilization patterns of waterbirds inhabiting the Lake wetlands is a fundamental issue for successful nature conservation and establish management guidelines.

Our findings suggest that, waterbird species inhabiting Tonga wetland have certain similarity in using the different habitat categories, which leads to cluster them into 5 guilds. In ecology, guild is a group of species that exploit the same kinds of resources in comparable ways (Ntiamoa-Baidu et al., 1996; Pérez-Crespo et al., 2013; Liordos, 2010). Accordingly, to the number of species in each guild and their levels of conservation concern, the seven studied microhabitats havecertain relevant differences in their importance for the citation species.

Firstly, open water body was used during the wintering season by the discussed species more than any other habitat categories; in other words, all most al the species (17 species) showed strong preferences for OWB habitat (Fig. 3). The high productivity of this habitat category is the main attractiveness feature for a wide range of waterbird species including dabbling ducks, diving ducks, coots and grebes. Elafri et al. (2016) suggest that almost all this space is shallow waters; the average depth at some central points is $0.5 \mathrm{~m}$ providing greater organic matter and submerged plant beds. These birds were still observed pecking and gathering emergent, submerging or floating aquatic plants and furthermore, trapping a wide variety of food items ranged from seeds to various invertebrates (Campbell et al.,1961; Ntiamoa-Baidu et al., 1996; Schmieder et al., 2006; Elafri et al., 2016), which suggests that this portion of the wetland area was the preferred feeding habitat, with other habitat types used as auxiliary areas. High concentrations of these birds on small space (OWB present $23.58 \%$ of total wetland surface) coupled with their narrow niche breadths (all of them are specialists, see results) will help in increasing interspecific competition (the found niche overlaps were larger among these species) and decreasing common resources, that will in turn result in reduced survivorship and recruitment. Several authors suggested that competitive interactions are more likely among species of the same guild (Jaksic, Medel 1990; Borges, Shanbhag, 2008; Pérez-Crespo et al., 2013). Also, species with narrower niche widths tend to be more affected by resources (habitat) fluctuation (Birand et al., 2012). Additionally, the previous study of waterbird community wintering in this wetland, Elafri et al. (2016) demonstrated that coots and Little grebes (both of which always accounted for more than $50 \%$ of all the individuals) were the most widespread species. These species by increasing their interspecific competition success for food and space, leading once more to reduced survivorship and recruitments of waterbird species, especially those with similar habitat needs such as dabbling and diving ducks that are among the most conspicuous inhabitants of wetland ecosystems and are very important game birds as well as in focus for habitat management and conservation efforts (Arzel, Elemberg, 2004).

Secondly, the flooded meadows and the juxtaposing areas (mudflats) were mostly exploited by wading species. These species showed strong preferences for these characteristic areas (Fig. 3). Several studies suggested that floodplain meadows provide a rich habitat for a range of shorebirds and other long-legged wading birds throughout the wintering season, particularly where there are areas of scrub or hedgerows on the drier ground (Brazner, Hoffman, 1991; Burger et al., 1997; Battisti et al., 2015). At this time of the year, especially during and 
after periodic flooding, floodplain meadows provide feeding grounds for these birds; they were often observed eating small invertebrates picked out of meadows, mudflat or exposed soil. Most of these species have declined significantly in recent years and are now classified as 'of conservation concern'(Battisti et al., 2015). This guild undergoes the previous scenario, it comprised specialist species that were highly concentrated in small area (FLM represents $11.34 \%$ of the wetland surface) and have an increasing niche overlaps, which could render them more prone to habitat fluctuations and interspecific competitions.

Then, the floating-leafed vegetation habitats are small islets patched in the middle of the lake and formed by very dense, submerged and floating vascular plants, principally the European white water-lily Nymphaea alba. This habitat category were highly preferred by mallards, gulls and cormorants (Fig. 3); they often used it as roosting areas (pers.obs.). Also, the two herons- Little egret and Grey heron- constitute a roosting colony on this small islet, far from the lake edge. Despite the narrow niche breadths of these birds, their existence may be less influenced through interspecific competition (they showed the minimum of niche overlap values). These guilds consider thismicrohabitat for roosting space and not for foraging, therefore they compete less within the bird community.

Finally, tall emergent vegetation, uncultivated and cultivated field have a lower electivity among the discussed microhabitats during the study period, since a majority of the species included in this study tended to avoid these habitats (Fig. 3). Dabbling, diving ducks and grebes avoided the dense emergent vegetation because this vegetative cover potentially restricted their movement and foraging efficiency in the study area. Such types of finding have also been reported by Van Rees-Siewert and Dinsmore (1996), King, Wrubleski (1998) and Benoit, Askins (1999). Dense vegetation might interfere with the movement and foraging efficiency of the waterbirds. In contrast, the grey heron and great egret exhibited a certain preference for this emergent vegetation (Fig. 3). This might be due to diverse food resources occurring in emergent vegetation (e.g., amphibians, fish and aquatic invertebrates). It is well known that egrets also selected the emergent vegetation with shallow water for their foraging activity (Rajpar, Zakaria, 2011).We must mention here that herons ascertained a different pattern of habitat utilization in Tonga wetland (niche breadth and overlap). In general, they occurred in several habitat categories, thereby having large niche breadths and less overlaps. The ability of these guilds to exploit resources in several habitats of the lake allowed segregation, thus decreasing potential inter- and intraspecific interactions. Uncultivated and cultivated field have been exclusively frequented by Cattle egret. This bird often observed foraging in this habitat, all most all the time associated with cattle herds.

\section{Conclusions and regional perspective}

Several authors found similar patterns of niche overlap, niche breadth and habitat utilization of waterbirds wintering in Mediterranean wetland and similar areas around the world. Our results showed that waterbird species in Tonga wetland were specialists in resource utilization patterns and therefore vulnerable to fluctuations in resources, particularly feeding habitats. Also, we found that only three microhabitats out of seven were the most important for the citation species; open water body was the most attractive, followed by meadows and muddy 

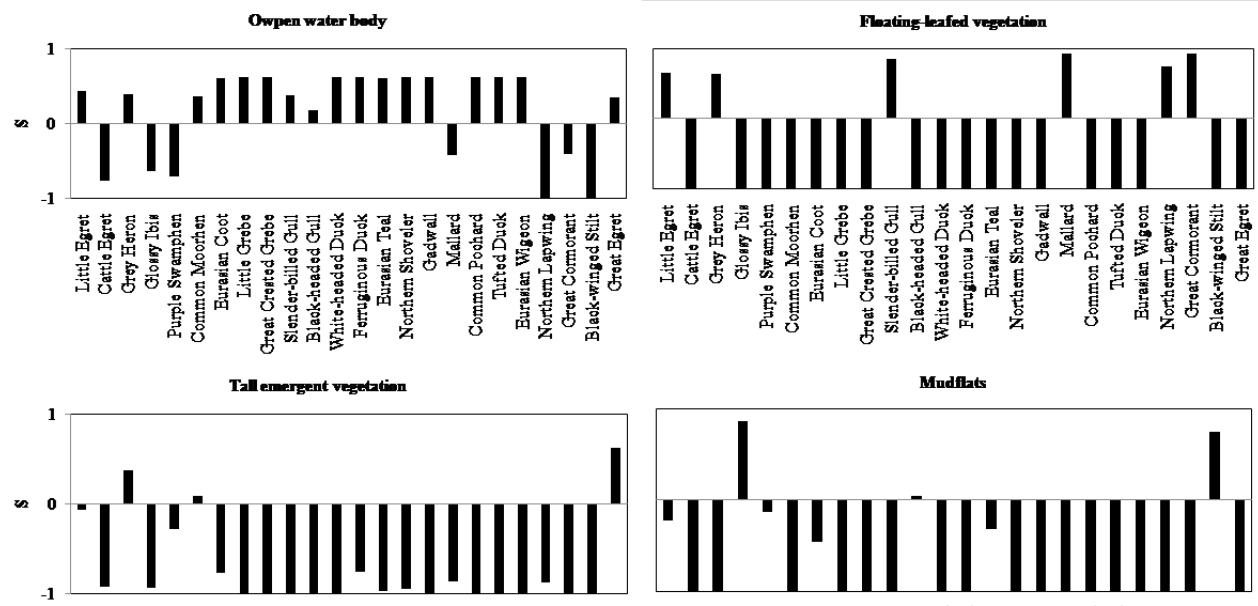

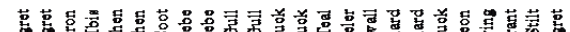

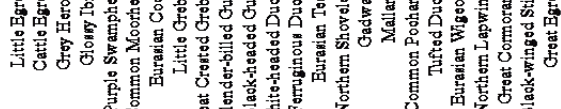

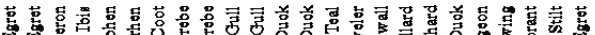

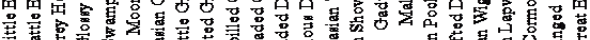

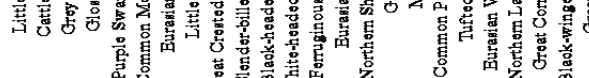

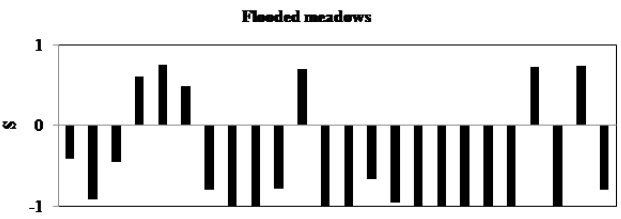

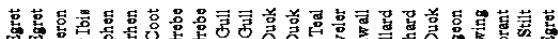

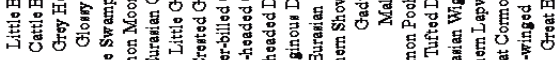

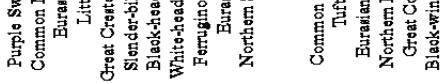

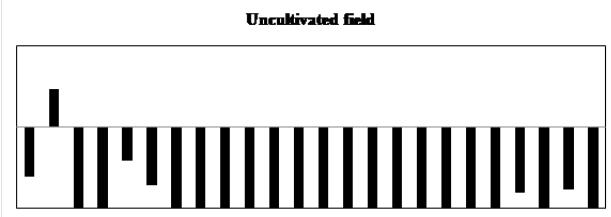

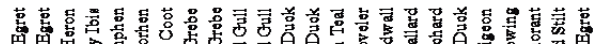

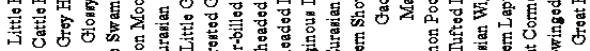

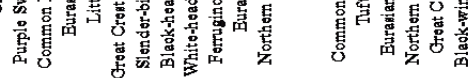

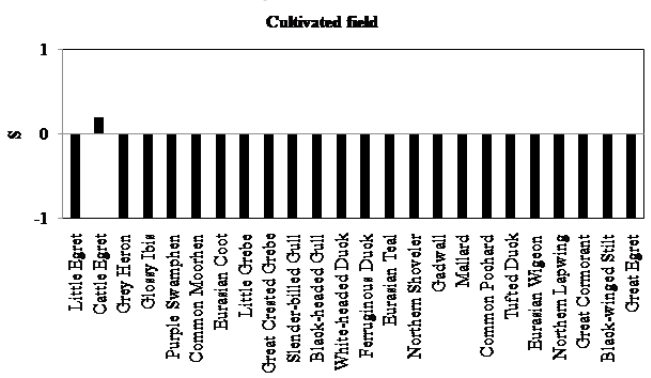

Fig. 3. Species comparison of Ivlev's Electivity Index (S) for the seven selected habitat types in Tonga wetland (northeast Algeria) in the 2014-2015 non-breeding period. 
areas. Although, this Ramsar site (satisfying 1,2, 3,5 and 6 of the nine criteria for identifying Wetlands of International Importance) stands as one of the most distinctive natural reserves in the North African coast, Elafri et al. (2016) suggest that the lake wetland may lose its resilience in the face of changing environment due to the decreasing species diversity and species homogenization. Despite that, waterbird species have various, and even contrasting habitat requirements, that said, management for some species may reduce habitat quality for others, and suggests that wetland management must be based on the region-specific knowledge about waterbird communities (Ma et al., 2009). Similarities on habitat requirements derived from our region can provide important and optimal wetland management at multi-species assemblage level. So, in order to attract and provide suitable habitat for waterbirds at local scale of Tonga wetland in the non-breeding period we can:

Increase open water body size, especially shallow waters by decreasing the emergent vegetation densities and controlling hydrological regimes. Pérez-Crespo et al. (2013) suggested that shallow waters can accommodate morespecies than deep waters. Many techniques have been used for this, including cutting by boat, mowing, ploughing and chemical herbicides (Duncan, d'Herbes, 1982).Controlling variation in water depth can be monitored by manipulating the artificial channel linking the wetland into the Mediterranean Sea, and surveying water pumping.

Enhancing water quality and controlling nutrient amount (maintaining standard water quality to avoid intense eutrophication)by supervising agricultural practices around field borders, $25.32 \%$ of the wetland area is an agricultural field.

Strategies promoted by wetland practitioners should be addressed to increase suitable meadows and muddy areas that are the second important habitat categories of the wetland, when a large number of waders occur during the migratory pass, in order to increase richness and diversity of these rare and declining species of conservation concern (e.g., included in Annex 1 of 79/409/CEE and 147/2009/CE 'Birds'Directives: BirdLife International, 2004; Battisti et al., 2015).

\section{References}

Arzel, C. \& Elemberg J. (2004). Time use, foraging behaviour and microhabitat use in a temporary guild of springstaging dabbling ducks (Anas spp.). Ornis Fenn., 81, 157-168.

Battisti, C., Boano, A., Cento, M., Circosta, A. \& Muratore S. (2015). Waders (Aves, Charadriiformes) in a Mediterranean remnant wetland, a year-round pilot study evidences contrasting patterns in diversity metrics. Rivista Italiana di Ornitologia - Research in Ornithology, 85(1), 61-66. DOI: 10.4081/rio.2015.136.

Benoit, L.K. \& Askins R.A. (1999). Impact of the spread of Phragmites on the distribution of birds in Connecticut tidal marshes. Wetlands, 19, 194-208. DOI: 10.1007/BF03161749.

Birand, A., Vose, A. \& Gavrilets S. (2012). Patterns of species ranges, speciation, and extinction. Am. Nat., 179(1), 1-21. DOI: $10.1086 / 663202$.

BirdLife International (2004). Birds in Europe: population estimates, trends and conservation status. BirdLife Conservation Series No.12. Cambridge.

Borges, S.D. \& Shanbhag A.B. (2008). Food resources partitioning among waterbirds wintering on the Diwar wetland in the Mandovi estuary of Goa, India. In M. Sengupta \& R. Dalwani (Eds.), Proceeding of Taal 2007, The $12^{\text {th }}$ World Lake Conference (pp. 124-130). India.

Both, C., Van Turnhout, C.A., Bijlsma, R.G., Siepel, H., Van Strien, A.J. \& Foppen RP. (2010). Avian population consequences of climate change are most severe for long- distance migrants in seasonal habitats. Proc. R. Soc. B, 277, 1259-1266. DOI: 10.1098/rspb.2009. 
Boumezbeur, A. (1993). Ecologie et biologie de la reproduction de l'Erismature à tête blanche (Oxyura leucocephala) et du Fuligule nyroca (Aythya nyroca) sur le lac Tonga et le lac des oiseaux (Est algérien). (Mesures de protection et de gestion du lac Tonga). Doctorat, Université des hautes études Montpellier.

Brazner, J. \& Hoffman J. (1991). Resource use patterns of the wading bird communities at two intertidal salt marshes on Sapelo Island. Final report. Problems in Oceanography, 750, 12/16/91.

Burger, J., Niles, L. \& Clark K.E. (1997). Importance of beach, mudflat and marsh habitats to migrant shorebirds on Delaware Bay. Biol. Conserv., 79, 283-292. DOI: 10.1016/S0006-3207(96)00077-8.

Campbell, A.M., Zim, H.S. \& Nelson A.L. (1961). American wildlife éplants : a guide to wildlife food habits: the use of trees, shrubs, weeds, and herbs by birds and mammals of the United States. Courier Corporation.

Colwell, R.K. \& Futuyma D.J. (1971). On the measurement of niche breadth and overlap. Ecology, 52(4), 567-576. DOI: $10.2307 / 1934144$.

Duncan, P. \& d'Herbes J.M. (1982). The use of domestic herbivores in the management of wetlands for waterbirds in the Camargue, France. In D.A. Scott (Ed.), Managing wetlands and their birds (pp. 51-66). Slimbridge: International Waterfowl Research Bureau.

Elafri, A., Halassi, I. \& Houhamdi M. (2016). Diversity patterns and seasonal variation of the waterbird community in Mediterranean wetlands of Northeastern Algeria. Zoology and Ecology, 26(2), 85-92. DOI: 10.1080/21658005.2016.1163865.

Elmberg, J., Nummi, P., Pöysä, H., Sjöberg, K., Gunnarsson, G., Clausen, P., Guillemain, M., Rodrigues, D. \& Väänänen V.M. (2006). The scientific basis for new and sustainable management of migratory European ducks. Wildl. Biol., 12, 121-127. DOI: 10.2981/0909-6396(2006)12[121:TSBFNA]2.0.CO;2.

Feinsinger, P., Spears, E.E. \& Poole R.W. (1981). A simple measure of niche breadth. Ecology, 62, 27-32. DOI: $10.2307 / 1936664$.

Fouzari, A., Samraoui, F., Alfarhan, A.H. \& Samraoui B. (2015). Nesting ecology of Ferruginous DuckAythya nyroca in north-eastern Algeria. Afr. Zool., 50, 299-305. DOI: 10.1080/15627020.2015.1108165.

Green, A.J. (1998). Comparative feeding behaviour and niche organization in a Mediterranean duck community. Can. J. Zool., 76, 500-507. DOI: 10.1139/z97-221.

Green, A.J. \& Hamzaoui M.E. (2000). Diurnal behaviour and habitat use of non-breeding Marbled Teal (Marmaronetta angustirostris). Can. J. Zool.,78, 2112-2118. DOI: 10.1139/z00-152.

IUCN (International Union for Conservation of Nature)(2012). 2012 IUCN Red list of threatened species. Available at http://www.iucnredlist.org [accessed 18 may 2016].

Jacobs, J. (1974). Quantitative measurements of food selection. A modification of the forage ratio and Ivlev's electivity index. Oecologia, 14, 413-417. DOI: 10.1007/BF00384581.

Jaksic, F.M. \& Medel R.G. (1990). Objective recognition of guilds, testing for statistically significant species clusters. Oecologia, 82, 87-92. DOI: 10.1007/BF00318537.

King, R.S. \& Wrubleski D.A. (1998). Spatial and diel availability of flying insects as potential duckling food in prairie wetlands. Wetlands, 18, 100-114. DOI: 10.1007/BF03161448.

Krebs, C.J. (1999). Ecological methodology. Menlo Park: Addison-Wesley Publishers.

Lazli, A., Boumezbeur, A., Moali-Grine, N. \& Moali A. (2011). Évolution de la population nicheuse de l'érismature à têteblanche (Oxyura leucocephala) sur le lac Tonga (Algérie). Rev. Écol. (Terre Vie), 66, 173-181. http://hdl. handle.net/2042/55875

Liordos, V. (2010). Foraging guilds of waterbirds wintering in a Mediterranean Coastal Wetland. Zool. Stud., 49, 311-323.

Ma, Z., Cai, Y., Li, B. \& Chen J. (2010). Managing wetland habitats for waterbirds: an international perspective. Wetlands, 30(1), 15-27. DOI: 10.1007/s13157-009-0001-6.

Meziane, N., Samraoui, F. \& Samraoui B. (2014). Status and diurnal activity budget of non-breeding White-headed Ducks (oxyura leucocephala)in Algeria. Ostrich, 85, 177-184. DOI: 10.2989/00306525.2014.964790.

Ntiamoa-Baidu, Y., Piersma, T., Wiersma, P., Poot, M., Battley, P. \& Gordon Ch. (1996). Water depth selection, daily feeding routines and diets of waterbirds in coastal lagoons in Ghana. Ibis, 140, 89-103. DOI: 10.1111/j.1474919X.1998.tb04545.x.

Paracuellos, M. (2006). How can habitat selection affect the use of a wetland complex by waterbirds? Biodivers. Conserv., 15, 4569-4582. DOI: 10.1007/s10531-005-5820-z.

Pérez-Crespo, M.J., Fonseca, J., Pineda-López, R., Palacios, E. \& Lara C. (2013). Foraging guild structure and niche characteristicsof waterbirds in an epicontinental lake in Mexico. Zool. Stud., 52, 54. DOI: 10.1186/1810-522X52-54. 
Pianka, E.R. (1973). The structure of lizard communities. Ann. Rev. Ecol. Syst., 4, 53-74. DOI: 10.1146/annurev. es.04.110173.000413.

Rajpar, M.N. \& Zakaria M. (2011). Bird species abundance and their correlationship with microclimate and habitat variables at natural wetland reserve, Peninsular Malaysia. International Journal of Zoology, 2011, 17. DOI: $10.1155 / 2011 / 758573$.

Rizzo, E. \& Battisti C. (2009). Habitat preferences of Anatidae (Aves, Anseriformes) in a Mediterranean patchy wetland (central Italy). Ekológia (Bratislava), 28, 66-73.

Samraoui, B. \& Samraoui F. (2008). An ornithological survey of the wetlands of Algeria, Important Bird Areas. Ramsar sites and threatened species. Wildfowl, 58, 71-98.

Schmieder, K., Werner, S. \& Bauer H.G. (2006). Submersed macrophytes as a food source for wintering waterbirds at Lake Constance. Aquat. Bot., 84, 245-250. DOI: 10.1016/j.aquabot.2005.09.006.

Shine, C. \& Klemm C. (1999). Wetlands, water and the law, using law to advance wetland conservation and wise use. Gland: IUCN.

Sulphey, M.M. \& Safeer M.M. (2014). Introduction to environment management. PHI Learning Private Limited.

Tellería, J.L. (2016). Wildlife habitat requirements, concepts and research approaches. In R. Mateo, B. Arroyo \& J.T. Garcia (Eds.), Current trends in wildlife research (pp. 79-95). Springer. DOI: 10.1007/978-3-319-27912-1_4.

Van Rees-Siewert, K.L. \& Dinsmore J.J. (1996). Influence of wetland age on bird use of restored wetlands in Iowa. Wetlands, 16, 577-582. DOI: 10.1007/BF03161348.

Wood, K.A. \& Stillman R.A. (2014). Do birds of a feather flock together? Comparing habitat preferences of piscivorous waterbirds in a lowland river catchment. Hydrobiologia, 738, 87-95. DOI: 10.1007/s10750-014-1921-6. 